\title{
Influence of red grape pomace powder on physiochemical, antioxidant, nutritional, microbial, and sensory properties of probiotic yoghurt
}

\author{
Shaghayegh Haghighat $\operatorname{Navaz}^{1}$ and Barat Ali Zarei Yam²
}

Received: 11 April 2021 / Accepted: 08 May 2021 / Published online: 27 July 2021

(C) Indian Dairy Association (India) 2021

\begin{abstract}
In this study, we investigated the effect of 2 and $4 \%$ grape pomace powder (GPP) on the physiochemical, nutritional, microbial and sensory properties of probiotic yoghurt (contains Lactobacillus acidophilus and Bifidobacterium bifidum) during the storage period every 7 -day intervals (for 28 days). The results revealed that the $\mathrm{pH}$, fat, protein, syneresis and sensory scores of samples decreased with elevation the grape pomace powder (GPP) level and also storage time. Ash, fiber, energy, total flavonoid, antioxidant activity, total phenol and the counting $(\log \mathrm{cfu} / \mathrm{mL})$ of probiotic microorganisms decreased during storage, but the treatments with higher GPP had higher ash, fiber, energy, total flavonoid, antioxidant activity, total phenol content and probiotic counts. In converse, the acidity and viscosity increased with time storage and increase the GPP level. The probiotic yoghurt supplanted with 4\% GPP in 0 day had the highest ash $(1.2 \%)$, fiber $(0.75 \%)$, energy $(73.8 \mathrm{kcal} / \mathrm{g})$, total flavonoid (4.9 mg Rutin equivalents/g) and antioxidant activity $(42.4 \%)$. The highest viable count at the end of storage period (28 day) was obtained for probiotic yoghurt containing 4\% GPP (8.03 $\log \mathrm{cfu} / \mathrm{mL})$ and the lowest for control (6.2 $\log \mathrm{cfu} / \mathrm{mL})$. Also the highest organoleptical scores belonged to yoghurt supplemented with $2 \%$ GPP at 0 day. The results of this research showed that grape pomace can be used in the production of probiotic yoghurt.
\end{abstract}

Keywords: Antioxidant, Grape pomace, Organoleptic, Probiotic yoghurt, Protein, Viscosity

${ }^{1}$ Sari Branch, Islamic Azad University, Sari, Iran ${ }^{2}$ Gorgan University of Agricultural Sciences and Natural Resources, Gorgan, Iran

Shaghayegh Haghighat Navaz ( $\square)$

Sari Branch, Islamic Azad University, Sari, Iran

Email: shaghighatnavaz@gmail.com

\section{Introduction}

Yoghurt is a fermented dairy product that is fermented and acidified by addition of a starter culture containing fermenting lactic acid bacteria including Streptococcus thermophilus and Lactobacillus delbrueckii ssp. bulgaricus. Yoghurt has gained widespread consumer acceptance as a healthy food providing health benefits. The functionality of yoghurt increases with the addition of probiotic microorganisms. Probiotics are living microorganisms having beneficial effect on host health (Pereira and Gibson 2002). The most commonly used probiotic microorganisms in dairy food are L. acidophilus and B. bifidum, which are chosen for their nutritive, therapeutic, and symbiotic characteristics (Hull et al. 1984, Gomes and Malcata 1999). Prebiotics are non-digestible carbohydrate substrates in the diet that are the preferred foods for Bifidobacteria and Lactobacilli and result in their increased number in the large intestine (Gibson and Roberfroid 1995). Grape (Vitis sp., Vitaceae) is one of the world's largest fruit crops, with an approximate annual production of 58 million metric tons (Zhu et al. 2014, Llobera and Caňellas 2007, Schieber et al. 2001). Winemaking process uses a considerable amount of fresh grape generating a huge mass of solid by-products. This by-product, usually referred to as grape pomace (GP), is generated after destemming and pressing grapes and is composed of grape seeds and skins (Cheng et al. 2010). In a study chemical composition of grape pomace evaluated. With regard to the compounds with functional properties, higher values of total dietary fiber $(46.17 \mathrm{~g} / 100 \mathrm{~g})$, insoluble fiber $(36.4$ $\mathrm{g} / 100 \mathrm{~g})$, carbohydrate $(29.2 \mathrm{~g} / 100 \mathrm{~g})$, protein $(8.49 \mathrm{~g} / 100 \mathrm{~g})$, lipids (8.16 g/100 g), energy (224 kcal/100 g), vitamin C (26.25 mg /100 $\mathrm{g})$, and anthocyanins (131 mg/100 g) were found. The minerals iron, potassium, zinc, manganese, and calcium were present in higher concentrations (Sousa et al. 2014). As mentioned above, grape pomace is a rich source of polyphenols and fibers. Agte et al. (2010) demonstrated prebiotic activity in grape varieties and hybrids that showed from 21.2 to $72.5 \%$ of the activity of fructooligosaccharide (FOS) used as a standard prebiotic. In this sense, Dairy products, such as yoghurts, are interesting foods in which grape pomace may be added, due to its positive effect on probiotic bacteria and consumers that prefer natural fibers instead of synthetic ingredients (Ramos et al. 2017). Some researchers studied the effect of the grape (juice, skin, seed, pomace, flour, 
oligofructose, extract) on the physiochemical, textural, sensory, nutritional, antioxidant and microbiological properties of yoghurt (Oztürk and Oner 1999, Karnopp et al. 2017, Dos Santos et al. 2017, Hervert-Herna'ndez et al. 2009, Da Silva et al. 2017, Karaaslan et al. 2011, Chouchouli et al. 2013, Lachman et al. 2013, Gil-Sánchez et al. 2017). Also, consumption of fruits, prebiotics and yoghurt in combination has a potential to provide extra nutritionalphysiological value that involve in synergetic effect on health such as cancer and cardiovascular disease (Espírito-Santo et al. 2010, Kourkoutas et al. 2006, Sendra et al. 2008, Karaaslan et al. 2011). Although the utilization of grape pomace in yoghurt was already the target of investigations (Marchiani et al. 2016), there is no comprehensive information about the physiochemical, microbial and sensory properties of fortified probiotic yoghurt with red pomace powder. Hence, we evaluated the combined effect of grape pomace powder and probiotic bacteria, Lactobacillus acidophilus and Bifidobacterium bifidum on some quality and traits of yoghurt and produced a yoghurt formulation based on sensorial, nutritional, and functional perspectives. Therefore, the objectives of this study were to investigate grape pomace potential as a functional ingredient for yoghurt production, and to evaluate the chemical, physical, microbial and sensory properties of the product during refrigerated storage (4 $\left.{ }^{\circ} \mathrm{C}\right)$.

\section{Materials and Methods}

\section{Materials}

Whole pasteurized cow milk used to prepare yoghurt formulations. Lyophilized pouches of commercial ABY culture (containing Lactobacillus acidophilus LA-5, Bifidobacterium bifidum BB12, Lactobacillus delbrueckii ssp. bulgaricus and Streptococcus thermophilus) and Y culture (containing commercial yoghurt starter culture, Lactobacillus delbrueckii ssp. bulgaricus and Streptococcus thermophilus) supplied by Christian Hansen (Horsholm, Denmark). The cultures maintained according to manufacturer's instructions at $-18{ }^{\circ} \mathrm{C}$ until use. Red wine grape pomace obtained from an industry of fruit pulp locate in the city of Gorgan (Iran). The pomace of grape fruit dried in oven under air flow at $60{ }^{\circ} \mathrm{C}$ until constant weight. The dried residue reduced to fine powder in a bimby processor. In order to make the mixture of the powder into the reconstituted milk easier, the particle size standardized to less than $0.42 \mathrm{~mm}$, measured through sieves. The powder stored in clapped glass bottles and kept under refrigeration at $4{ }^{\circ} \mathrm{C}$ until use.

\section{Yoghurt production}

Milk standardized to $14 \%$ (w/v) total solids with skimmed milk powder. The mixture was pasteurized at $85^{\circ} \mathrm{C}$ for $30 \mathrm{~min}$ and cooled to $43{ }^{\circ} \mathrm{C}$ and inoculated with the standard yoghurt culture (Y) and the working cultures of L. acidophilus and B. bifidum at the level of $1 \%(\mathrm{v} / \mathrm{v})$. For the preparation of fruit incorporated yoghurt, 2 and $4 \%(\mathrm{w} / \mathrm{v})$ red grape pomace powder added to the milk before adding skim milk powder during the standardization. The mixture was incubated at $42{ }^{\circ} \mathrm{C}$ until the $\mathrm{pH}$ reached 4.5. After the fermentation, the samples were transfered into a refrigerator at $4{ }^{\circ} \mathrm{C}$ and then stored at $4{ }^{\circ} \mathrm{C}$ for 28 days. $\mathrm{pH}$, total titratable acidity, protein, fat, ash, total dietary fiber, energy, syneresis, viability of probiotic organisms, total phenolic content, total flavonoid content, antioxidant activity, viscosity and sensory properties were determined during the storage period every 7-day intervals.

\section{Chemical and nutritional attributes}

$\mathrm{pH}$ values of the samples measured using a $\mathrm{pH}$ meter. The titratable acidity (Dornic, ${ }^{\circ} \mathrm{D}$ ) determined after mixing $10 \mathrm{~mL}$ of sample with $10 \mathrm{~mL}$ of distilled water and titrating with $0.1 \mathrm{~N} \mathrm{NaOH}$ using phenolphethalein as indicator (Ahmadi et al. 2012). Ash content was detected according to Sowbhagya et al. (2007). Fat was measured gravimetrically by extraction with diethyl ether using a Soxhlet apparatus (AOAC 1990). Nitrogen content was detected by Kjeldahl method (Ayadi et al. 2009). Total dietary fiber content determined with using of the Megazyme International total DF assay (Sun-Waterhouse et al. 2010). The total energy was measured based on the energy nutrient results obtained using the conversion factors of Atwater, as described by Sousa et al. (2014) considering $4 \mathrm{kcal} / \mathrm{g}$ for carbohydrate, 4 $\mathrm{kcal} / \mathrm{g}$ for protein, and $9 \mathrm{kcal} / \mathrm{g}$ for lipids. Syneresis determined by measuring the volume of separated whey (mL whey/ $100 \mathrm{~mL}$ yoghurt) after $30 \mathrm{~min}$ at room temperature (Abd El-Salam et al. 1991).

\section{Total phenolic content}

Total phenolic content was measured according to Zheng and Wang (2001) by using Folin-Ciocalteu reagent. The absorbance measured with a UV-ViS Spectrophotometer at $765 \mathrm{~nm}$. The absorbance values were converted to the total phenolics and were expressed as $\mu \mathrm{g}$ gallic acid equivalents per gram sample ( $\mu \mathrm{g}$ $\mathrm{GAE} / \mathrm{g})$.

\section{Total flavonoid content}

The amount of total flavonoid content (TFC) in the extracts was detected spectrophotometrically according to Djeridane et al. (2006). This method depends on the formation of a complex flavonoid aluminum, having the maximum absorbance at $430 \mathrm{~nm}$. Rutin was used to make a calibration curve. TFC expressed as $\mathrm{mg}$ Rutin equivalents per $\mathrm{g}$.

\section{Antioxidant activity}

Antioxidant activites of yoghurt samples by 2,2-diphenyl-1picrylhydrazyl radical (DPPH) inhibition were determined. Yoghurt water extract $(250 \mu \mathrm{L})$ was added into $3 \mathrm{~mL}$ of $60 \mu \mathrm{M}$ DPPH in ethanol. The decrease in absorbance monitored at $517 \mathrm{~nm}$ until a 
constant reading obtained. The readings compared with the control which contained distilled water $(250 \mu \mathrm{L})$ (Apostolidis et al. 2007). The inhibition percentage calculated as follows:

$\%$ Inhibition $=($ A control"A sample $) \times 100 /$ A control

\section{Viscosity}

The apparent viscosity of samples was measured using a rotary Brookfield Viscometer(RVDV2, Brookfield, MA, USA) with RV4 spindle. Before starting the test, all samples were kept at $7^{\circ} \mathrm{C}$ in constant conditions to remove any stress or change in their texture. Viscosity of each treatment was carried out at $80 \mathrm{rpm}$ shear stress during $60 \mathrm{~s}$. The test type was as single point (Trachoo and Mistry 1998).

\section{Probiotic Count}

MRS-bile agar medium used for the selective enumeration of $L$. acidophilus and bifidobacteria (Sohrabvandi et al. 2012). The plates incubated anaerobically at $37^{\circ} \mathrm{C}$ for $72 \mathrm{~h}$. Anaerobic conditions produced using the GasPack system. Number of probiotics calculated and expressed as cfu/mL (Shafiee et al. 2010).

\section{Sensory Analysis}

Yoghurt samples were subjected into a sensory evaluation with 10 untrained panelists. The yoghurt samples were served in white plastic pots in individual booths under light exposure. The sensory evaluation carried out using a five-point hedonic scale (5- like very much to 1 - dislike very much) based on acceptance to the product in order to evaluate the degree of likeliness for selected quality attributes i.e. flavor, appearance, consistency, taste, and overall acceptability (Senadeera et al. 2018).

\section{Statistical analysis}

The data obtained from the measurements were subjected to analysis of variance (ANOVA) to determine the significant differences among the samples, and the values were compared using the Duncan's test defined at Pd'0.05. All measurements were carried out in triplicate and reported as the mean \pm SD. The data analysis was performed using SPSS software version 16 (SPSS Inc., Chicago, IL, USA).

\section{Results and Discussion}

Effect of incorporation of grape pomace powder on physiochemical, antioxidant and nutritional properties of probiotic yoghurt

Chemical and nutritional properties of different yoghurt samples during 28 days storage is presented in Table 1 . The $\mathrm{pH}$ of all yoghurt samples decreased throughout storage period, while the acidity increased. This was due to the growth of lactic acid bacteria and produced the lactic acid (Rasic et al. 1978). The values of $\mathrm{pH}$ and acidity recorded in this study were consistent with the results obtained by Mahmood et al. (2008) and Tarakci (2010).

The fat and protein of samples were decreased with increase the grape pomace powder (GPP) and also during storage time, while

Table 1 Physiochemical and nutritional parameters of different yoghurt formulations during storage period (mean \pm SD)

\begin{tabular}{|c|c|c|c|c|c|c|c|c|c|}
\hline & $\begin{array}{l}\text { Day } \\
\text { Treatment }\end{array}$ & $\mathrm{pH}$ & $\begin{array}{l}\text { Acidity } \\
\left({ }^{\circ} \mathrm{D}\right)\end{array}$ & $\begin{array}{l}\text { Protein } \\
(\%)\end{array}$ & $\begin{array}{l}\text { Fat } \\
(\%)\end{array}$ & $\begin{array}{l}\text { Ash } \\
(\%)\end{array}$ & $\begin{array}{l}\text { Fiber } \\
(\%)\end{array}$ & $\begin{array}{l}\text { Energy } \\
(\mathrm{kcal} / \mathrm{g})\end{array}$ & $\begin{array}{c}\text { Syneresis) } \\
\text { (mL whey/ } \\
100 \mathrm{~mL} \\
\text { yoghurt }\end{array}$ \\
\hline \multirow[t]{3}{*}{ control } & 0 & $4.8 \pm 0.1^{\mathrm{g}}$ & $80 \pm 1.7^{\mathrm{a}}$ & $3.2 \pm 0.1^{\mathrm{a}}$ & $3.4 \pm 0.2^{\mathrm{f}}$ & $0.8 \pm 0.1^{\mathrm{a}}$ & $0.07 \pm 0.01^{\mathrm{a}}$ & $70 \pm 1.1^{\mathrm{ab}}$ & $50 \pm 2.2^{\mathrm{k}}$ \\
\hline & 7 & $4.6 \pm 0.1^{\mathrm{fg}}$ & $82.0 \pm 2^{b}$ & $3.2 \pm 0.2^{\mathrm{a}}$ & $3.4 \pm 0.2^{\mathrm{f}}$ & $0.8 \pm 0.1^{\mathrm{a}}$ & $0.07 \pm 0.01^{\mathrm{a}}$ & $70 \pm 2.1^{\mathrm{ab}}$ & $49.9 \pm 2.1^{\mathrm{k}}$ \\
\hline & 14 & $4.6 \pm 0.2^{\mathrm{fg}}$ & $83.0 \pm 3.2^{b}$ & $3.15 \pm 0.2^{\mathrm{a}}$ & $3.3 \pm 0.1^{\text {ef }}$ & $0.78 \pm 0.2^{\mathrm{a}}$ & $0.07 \pm 0.01^{\mathrm{a}}$ & $69.6 \pm 2.2^{\mathrm{ab}}$ & $46.7 \pm 1.7^{\mathrm{j}}$ \\
\hline \multirow[t]{5}{*}{$2 \%$ GPP } & 0 & $4.7 \pm 0.3^{\mathrm{g}}$ & $83.0 \pm 1.1^{\mathrm{b}}$ & $3.0 \pm 0.3^{\mathrm{a}}$ & $3.2 \pm 0.3^{\text {cde }}$ & $1.08 \pm 0.21^{\mathrm{bcd}}$ & $0.38 \pm 0.08^{b}$ & $72 \pm 2.3^{\text {def }}$ & $44.3 \pm 2^{\mathrm{i}}$ \\
\hline & 7 & $4.3 \pm 0.11^{\mathrm{defg}}$ & $87.0 \pm 2.2^{\mathrm{d}}$ & $3.0 \pm 0.24^{\mathrm{a}}$ & $3.18 \pm 0.21^{\mathrm{cde}}$ & $1.07 \pm 0.04^{\mathrm{bc}}$ & $0.38 \pm 0.06^{b}$ & $72 \pm 3.4^{\mathrm{def}}$ & $43.8 \pm 3^{\mathrm{h}}$ \\
\hline & 14 & $4.0 \pm 0.21^{\mathrm{bcde}}$ & $90.0 \pm 3.4^{\mathrm{e}}$ & $2.9 \pm 0.34^{\mathrm{a}}$ & $3.16 \pm 0.17^{\text {bcde }}$ & $1.06 \pm 0.06^{b c}$ & $0.38 \pm 0.02^{\mathrm{b}}$ & $71.7 \pm 0.8^{\mathrm{de}}$ & $43.2 \pm 0.9^{\mathrm{g}}$ \\
\hline & 21 & $3.8 \pm 0.14^{\mathrm{abcd}}$ & $93.0 \pm 2.4^{\mathrm{f}}$ & $2.9 \pm 0.17^{\mathrm{a}}$ & $3.13 \pm 0.16^{\mathrm{bcd}}$ & $1.05 \pm 0.09^{\mathrm{b}}$ & $0.37 \pm 0.03^{\mathrm{b}}$ & $71.2 \pm 4.1^{\mathrm{cd}}$ & $39.2 \pm 1.5 \mathrm{e}^{\mathrm{i}}$ \\
\hline & 28 & $3.6 \pm 0.32^{\mathrm{abc}}$ & $97.0 \pm 2.8^{\mathrm{g}}$ & $2.8 \pm 0.14^{\mathrm{a}}$ & $3.1 \pm 0.2^{\mathrm{bc}}$ & $1.04 \pm 0.1^{\mathrm{b}}$ & $0.37 \pm 0.03^{\mathrm{b}}$ & $70.5 \pm 2.2^{\mathrm{bc}}$ & $36.4 \pm 1.2^{\mathrm{d}}$ \\
\hline \multirow{2}{*}{$4 \%$ GPP } & 21 & $3.5 \pm 0.33^{\mathrm{ab}}$ & $101.2 \pm 3.8^{\mathrm{h}}$ & $2.8 \pm 0.1^{\mathrm{a}}$ & $3.0 \pm 0.13^{\mathrm{ab}}$ & $1.15 \pm 0.05^{\mathrm{cde}}$ & $0.74 \pm 0.04^{\mathrm{c}}$ & $72.6 \pm 1.4^{\mathrm{efg}}$ & $30.9 \pm 0.5^{b}$ \\
\hline & 28 & $3.4 \pm 0.18^{\mathrm{a}}$ & $105.4 \pm 2.5^{\mathrm{i}}$ & $2.7 \pm 0.1^{\mathrm{a}}$ & $2.9 \pm 0.08^{\mathrm{a}}$ & $1.13 \pm 0.03^{\text {bcde }}$ & $0.74 \pm 0.01^{\mathrm{c}}$ & $72.1 \pm 2.2^{\text {def }}$ & $30.2 \pm 0.8^{\mathrm{a}}$ \\
\hline
\end{tabular}

Values are given as mean $\pm \mathrm{SD}$.

Different letters in the same column indicate significant differences $(\mathrm{p}<0.05)$. 
Fig 1. Variation in the viscosity of different probiotic yoghurt formulations during storage period. Values are given as mean $\pm \mathrm{SD}$. Different letters indicate significant differences $(\mathrm{P}<0.05)$.

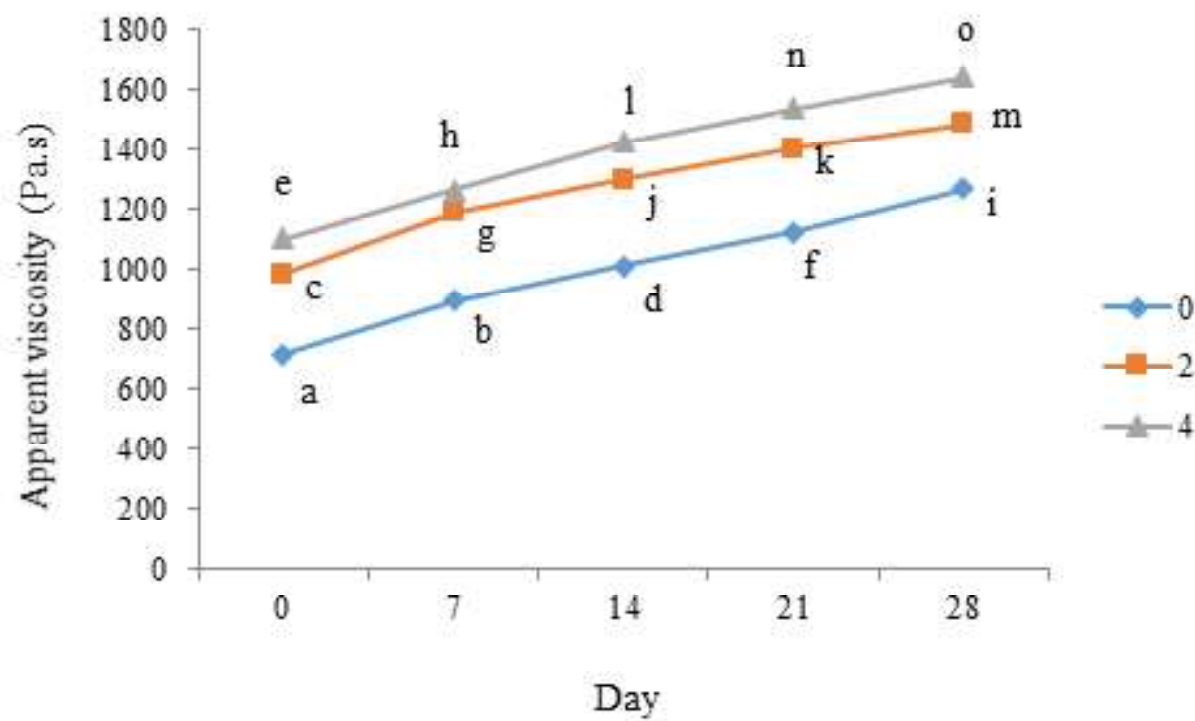

Table 2 Total phenol and flavonoid contents and Antioxidant activity of different probiotic yoghurt formulations during storage period (mean \pm SD)

\begin{tabular}{lllll}
\hline Treatment & Day & $\begin{array}{l}\text { Total phenolic } \\
(\mu \mathrm{g} \mathrm{GAE} / \mathrm{g})\end{array}$ & $\begin{array}{l}\text { Total flavonoid } \\
(\mathrm{mg} \text { Rutin equivalents } / \mathrm{g})\end{array}$ & $\begin{array}{l}\text { Antioxidant } \\
\text { activity }(\%)\end{array}$ \\
\hline control & 0 & $9.21 \pm 0.70^{\mathrm{ab}}$ & $1.0 \pm 0.03^{\mathrm{c}}$ & $21.40 \pm 1.30^{\mathrm{e}}$ \\
& 7 & $9.30 \pm 0.40^{\mathrm{c}}$ & $0.90 \pm 0.04^{\mathrm{b}}$ & $18.10 \pm 1.10^{\mathrm{d}}$ \\
& 14 & $9.12 \pm 0.30^{\mathrm{a}}$ & $0.80 \pm 0.05^{\mathrm{b}}$ & $16.70 \pm 1.00^{\mathrm{c}}$ \\
& 21 & $9.18 \pm 0.28^{\mathrm{ab}}$ & $0.60 \pm 0.02^{\mathrm{a}}$ & $14.30 \pm 0.80^{\mathrm{b}}$ \\
& 28 & $9.16 \pm 0.32^{\mathrm{ab}}$ & $0.50 \pm 0.01^{\mathrm{a}}$ & $12.20 \pm 0.60^{\mathrm{a}}$ \\
& 0 & $12.82 \pm 0.21^{\mathrm{d}}$ & $2.44 \pm 0.10^{\mathrm{g}}$ & $28.50 \pm 2.10^{\mathrm{a}}$ \\
& 7 & $13.10 \pm 20.22^{\mathrm{e}}$ & $2.10 \pm 0.10^{\mathrm{f}}$ & $26.10 \pm 2.00^{\mathrm{g}}$ \\
& 14 & $12.76 \pm 0.41^{\mathrm{d}}$ & $1.80 \pm 0.09^{\mathrm{e}}$ & $23.40 \pm 1.40^{\mathrm{f}}$ \\
& 21 & $12.70 \pm 0.10^{\mathrm{cd}}$ & $1.70 \pm 0.06^{\mathrm{e}}$ & $21.00 \pm 1.00^{\mathrm{e}}$ \\
& 28 & $12.60 \pm 0.18^{\mathrm{c}}$ & $1.50 \pm 0.12^{\mathrm{d}}$ & $18.30 \pm 0.50^{\mathrm{d}}$ \\
& 0 & $16.40 \pm 0.25^{\mathrm{f}}$ & $4.90 \pm 0.22^{\mathrm{f}}$ & $42.40 \pm 1.20^{1}$ \\
& 7 & $16.70 \pm 0.30^{\mathrm{g}}$ & $4.60 \pm 0.25^{\mathrm{k}}$ & $37.60 \pm 2.30^{\mathrm{k}}$ \\
& 14 & $16.60 \pm 0.27^{\mathrm{g}}$ & $4.20 \pm 0.27^{\mathrm{j}}$ & $33.20 \pm 2.10^{\mathrm{j}}$ \\
& 21 & $16.40 \pm 0.30^{\mathrm{f}}$ & $3.60 \pm 0.30^{\mathrm{i}}$ & $27.50 \pm 1.40^{\mathrm{h}}$ \\
& 28 & $16.30 \pm 0.27^{\mathrm{f}}$ & $3.20 \pm 0.26^{\mathrm{h}}$ & $23.10 \pm 1.00^{\mathrm{f}}$ \\
\hline \hline
\end{tabular}

Values are given as mean $\pm \mathrm{SD}$.

Different letters in the same column indicate significant differences $(\mathrm{P}<0.05)$.

the syneresis was decreased. The differences between protein of treatments were not significantly difference $(p>0.05)$. Ash, fiber and energy decreased during storage, but the treatments with higher GPP had higher ash, fiber and energy contents. The yoghurt supplemented with 4\% GPP in 0 day had the highest ash (1.2\%), fiber $(0.75 \%)$ and energy ( $73.8 \mathrm{kcal} / \mathrm{g}$ ) (Table 1). This result is due to low fat and protein, and high ash, fiber and energy content of grape pomace. Similarly, in research carried out by Karnopp et al. (2017), grape skin flour (GSF) increased the ash and total fiber contents of yoghurts that were in parallel with our findings. Conversely, Da Silva et al. (2017) reported that $\mathrm{pH}$, titratable acidity, ash, fat and moisture content of probiotic yoghurt supplemented with 1.5 and $3.0 \mathrm{~g} \mathrm{~L}^{-1}$ of grape extract that stored at $4^{\circ} \mathrm{C}$ were not significantly different $(\mathrm{P}<0.05)$.

Syneresis is the leakage of liquid from yoghurt. Syneresis is one of the key quality parameters for yoghurt. Higher level of syneresis revealed that yoghurt is of low quality (Lee and Lucey 2010). The syneresis of yoghurts were affected significantly $(\mathrm{P}<0.05)$ by both grape pomace concentration and storage time and the changes are presented in Table 1 . Syneresis values of different types of probiotic yoghurt varied from 30.2 to $50.0 \%$. This result was matched with (Tarakci and Kucukoner 2003). In the first day, the highest mean value $(50 \%)$ of syneresis was related to control and the lowest mean value (31.5\%) in sample containing $4 \%$ GPP. The addition of fruit pomace powder caused 
a decrease of syneresis in all samples of yoghurts and the differences between the control and these samples were statistically significant $(\mathrm{P}<0.05)$. It could be related to the capacity to absorb water by solids (fiber, carbohydrate and protein) that present in pomace powder which leads to a decrease of syneresis (Mahmood et al. 2008). But also controversial results also reported. For example, Da Silva et al. (2017) noted that syneresis increased with high concentration of grape extract. While Dos Santos et al. (2017) observed no differences for syneresis in yoghurt samples fortified with Pinot Noir grape juice and concentrated grape skin extract.

Since grape pulp contains a wide variety of phenolic compounds (Chung et al. 1998), its regular consumption reduces the risk of diseases such as cancer and cardiovascular diseases (Jang et al. 2010). Total phenolic, total flavonoid contents and antioxidant activity of probiotic yoghurt samples are shown in Table 2 . There were significant differences in the total phenolic, total flavonoid contents and antioxidant activity of the samples $(\mathrm{P}<0.05)$. All these factors were decreased throughout storage period. But also these factors for supplemented yoghurt samples were significantly $(p<0.05)$ higher than control samples. In a study, yoghurts supplemented with red grape and callus extracts displayed high phenolic and anthocyanin content and thus exhibited higher antioxidant power compared to yoghurts containing chardonnay extracts and control samples. The storage time significantly affected the free radical scavenging capacity of the yoghurts. The yoghurts supplied with grape callus extract displayed the greatest antioxidant power on the first day of storage compared to all the assayed samples (Karaaslan et al. 2011).

In our study, the highest total flavonoid (4.9 mg Rutin equivalents/ g) and antioxidant activity (42.4\%) recorded for yoghurt enriched with $4 \%$ GPP at 0 day that had significant differences with other treatments $(p<0.05)$. But the higher total phenolic $(16.7 \mu \mathrm{g} \mathrm{GAE} /$ g) content was obtained for yoghurt enriched with $4 \%$ GPP at 7 day. The higher values of these factors were for enriched probiotic yoghurts with grape pomace powder compared to control, it may be due to the high concentrations of antioxidant compounds of grape pomace (Leong and Shui 2002) have observed the highest activity using DPPH. Similar studies describe that the antioxidant activity of yoghurts was enhanced by the presence of natural extracts, for example, in studies with yoghurts fortified with white and red dragon fruit (Zainoldin and Baba 2009), grape seed (Chouchouli et al. 2013) or with wild blackberry (Martins et al. 2014) extracts. Generally, the development of dairy foods containing polyphenols and fibers from grape pomaces are a technological trend that can improve the nutritional and functional value of foods (Dos Santos et al. 2017, Lachman et al. 2013).

The viscosities of liquid and semisolid foods have a large impact on their quality properties (Karaman et al. 2014). Figure 1 is presented the viscosity of yoghurt samples during storage time. It was obvious that the apparent viscosity of all fruit yoghurts increase in proportion to increase percentage of pomace powder addition and also storage time. The lowest and highest viscosity recorded for control sample at 0 day (714 Pa.s), and yoghurt supplemented with 4\% GPP at 28 day storage (1644 Pa.s), respectively (Figure 1). In a study, purple grape juice (PGJ) increased the viscosity of yoghurt, but the combinations $50 \%$ grape skin flour (GSF) and 50\% oligofructose (OLI) and $66.7 \%$ GSF, $16.7 \%$ OLI and $16.7 \%$ PGJ presented the lowest mean values for viscosity (Karnopp et al. 2017). A similar trend was found by Öztürk and Öner (1999) for yoghurt containing concentrated grape juice. The fibers in Grape acted as stabilizer, forming colloidal solution (three dimensional network) that prevented water mobility, and so yielding high values of viscosity (Cruz et al. 2013).

\section{Effect of incorporation of grape pomace powder on microbial counts of probiotic yoghurt}

A sufficient number of viable microorganisms must be present throughout the entire shelf life of the product in order to produce therapeutic benefits. Although there is no world-wide agreement on the minimum of viable probiotic cells per gram or milliliter of probiotic product until the time of consumption, generally, the values of $10^{6}$ and $10^{7}-10^{8} \mathrm{cfu} / \mathrm{mL}$ or $\mathrm{cfu} / \mathrm{g}$ have been accepted as the minimum and satisfactory levels, respectively (Korbekandi et al. 2011, Tamime et al. 2005, Ahmadi et al. 2012, Mortazavian et al. 2008). Usually due to high acid content, presence of bacteriocins, and fermentation conditions, the survival ability of probiotic bacteria in yoghurt decreased before consumption (Ferdousi et al. 2013). Therefore, utilization of prebiotic compounds is a common method in order to increase the survival ability of these bacteria at the consumption time (Pharmaceutiques 1995). Prebiotic activity of grape previously reported (Agte et al. 2010). Viability ( $\log \mathrm{cfu} / \mathrm{mL}$ ) of probiotic microorganisms in different treatments during refrigerated storage $\left(4^{\circ} \mathrm{C}\right)$ for 28 days is presented in Figure 2. The probiotic microorganisms (log cfu/ $\mathrm{mL})$ in different treatments during refrigerated storage $\left(4^{\circ} \mathrm{C}\right)$ decreased by time, but also this decrease was lower in samples contain GPP. Although counts of probiotic bacteria decreased gradually during storage time, yoghurt samples held probiotic values of $10^{6} \log \mathrm{cfu} / \mathrm{mL}$ until day 28 . Vinderola and Reinheimer (1999) also stated that probiotic microflora counts decrease during storage. The rate of this loss in cell viability depended on the yoghurt type and the use of lactic starter. In current study the highest viable counts at the end of storage period (28 day) were obtained for probiotic yoghurt contain $4 \%$ GPP $(8.03 \log \mathrm{cfu} / \mathrm{mL})$ and the lowest for control $(6.2 \log \mathrm{cfu} / \mathrm{mL}$ ) (Figure 2). In a research carried out by Da Silva et al. (2017), bacterial strains were found in at least $10^{9} \mathrm{cfu} / \mathrm{g}$ of yoghurt showing the possibility of probiotic yoghurt production with grape extract that overlapped with current study as yoghurt containing 4\% GPP had $8.03 \log \mathrm{cfu} / \mathrm{mL}$ at the end of storage time (Figure 2). Also Ehsani et al. (2015) 
Fig 2. Viability ( $\log \mathrm{cfu} / \mathrm{mL})$ of probiotic microorganisms in different yoghurt samples during refrigerated storage $\left(4^{\circ} \mathrm{C}\right)$ for 28 days. Values are given as mean \pm SD. Different letters in the same column indicate significant differences $(\mathrm{P}<0.05)$.

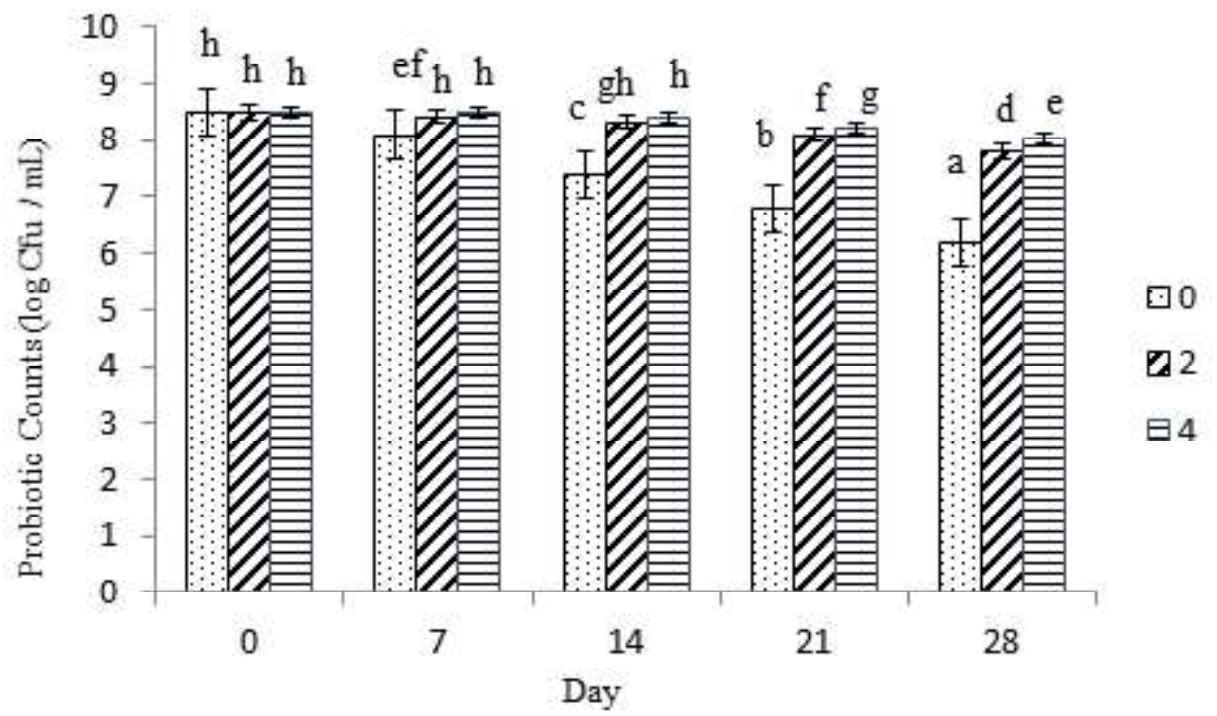

Table 3 Sensory analysis of the probiotic yoghurt treatments using score methodology

\begin{tabular}{|c|c|c|c|c|c|c|}
\hline Treatments & Day & Appearance & Taste & Consistency & flavor & Overall acceptability \\
\hline \multirow[t]{5}{*}{ control } & 0 & $5.0 \pm 0.20^{\mathrm{c}}$ & $4.5 \pm 0.20^{\mathrm{e}}$ & $4.7 \pm 0.10^{\mathrm{gh}}$ & $4.7 \pm 0.20^{\text {cde }}$ & $4.7 \pm 0.00^{\mathrm{g}}$ \\
\hline & 7 & $4.8 \pm 0.10^{\mathrm{bc}}$ & $4.3 \pm 0.10^{\mathrm{d}}$ & $4.5 \pm 0.20^{\text {ef }}$ & $4.5 \pm 0.10^{\text {bcde }}$ & $4.4 \pm 0.00^{\mathrm{f}}$ \\
\hline & 14 & $4.5 \pm 0.12^{\mathrm{abc}}$ & $4.0 \pm 0.08^{c}$ & $4.2 \pm 0.08^{\mathrm{bc}}$ & $4.2 \pm 0.20^{\mathrm{abc}}$ & $4.2 \pm 0.10^{\mathrm{de}}$ \\
\hline & 21 & $4.3 \pm 0.22^{\mathrm{abc}}$ & $3.8 \pm 0.06^{\mathrm{b}}$ & $4.0 \pm 0.06^{\mathrm{a}}$ & $4.0 \pm 0.00^{\mathrm{ab}}$ & $4.0 \pm 0.10^{\mathrm{bc}}$ \\
\hline & 28 & $4.2 \pm 0.14^{\mathrm{ab}}$ & $3.7 \pm 0.06^{\mathrm{ab}}$ & $4.0 \pm 0.05^{\mathrm{a}}$ & $3.8 \pm 0.08^{\mathrm{a}}$ & $3.8 \pm 0.20^{\mathrm{a}}$ \\
\hline \multirow[t]{5}{*}{$2 \%$ GPP } & 0 & $50 \pm 0.20^{\mathrm{c}}$ & $4.8 \pm 0.40^{\mathrm{f}}$ & $4.9 \pm 0.17^{\mathrm{i}}$ & $5.0 \pm 0.07^{\mathrm{e}}$ & $4.9 \pm 0.10^{\mathrm{h}}$ \\
\hline & 7 & $4.7 \pm 0.30^{\mathrm{bc}}$ & $4.5 \pm 0.30^{\mathrm{e}}$ & $4.8 \pm 0.14^{\mathrm{hi}}$ & $4.9 \pm 0.20^{\mathrm{e}}$ & $4.7 \pm 0.30^{\mathrm{g}}$ \\
\hline & 14 & $4.6 \pm 0.24^{\mathrm{bc}}$ & $4.2 \pm 0.10^{\mathrm{d}}$ & $4.6 \pm 0.15^{\mathrm{fg}}$ & $4.7 \pm 0.10^{\text {cde }}$ & $4.4 \pm 0.40^{\mathrm{f}}$ \\
\hline & 21 & $4.5 \pm 0.26^{\mathrm{abc}}$ & $4.0 \pm 0.00^{\mathrm{c}}$ & $4.4 \pm 0.27^{\mathrm{de}}$ & $4.3 \pm 0.30^{\mathrm{abcd}}$ & $4.3 \pm 0.00^{\mathrm{ef}}$ \\
\hline & 28 & $4.3 \pm 0.27^{\mathrm{abc}}$ & $3.8 \pm 0.08^{b}$ & $4.3 \pm 0.18^{\text {cd }}$ & $4.0 \pm 0.20^{\mathrm{ab}}$ & $4.2 \pm 0.10^{\mathrm{de}}$ \\
\hline \multirow[t]{5}{*}{$4 \%$ GPP } & 0 & $4.7 \pm 0.28^{\mathrm{bc}}$ & $4.6 \pm 0.12^{\mathrm{ef}}$ & $4.8 \pm 0.16^{\mathrm{hi}}$ & $4.8 \pm 0.20^{\mathrm{de}}$ & $4.7 \pm 0.10^{\mathrm{g}}$ \\
\hline & 7 & $4.5 \pm 0.21^{\mathrm{abc}}$ & $4.3 \pm 0.14^{\mathrm{d}}$ & $4.6 \pm 0.31^{\mathrm{fg}}$ & $4.7 \pm 20^{\text {cde }}$ & $4.6 \pm 0.30^{\mathrm{g}}$ \\
\hline & 14 & $4.3 \pm 0.18^{\mathrm{abc}}$ & $4.0 \pm 0.09^{c}$ & $4.5 \pm 0.24^{\mathrm{ef}}$ & $4.5 \pm 0.10^{\text {bcde }}$ & $4.4 \pm 0.10^{\mathrm{f}}$ \\
\hline & 21 & $4.1 \pm 0.19^{\mathrm{ab}}$ & $3.8 \pm 0.10^{\mathrm{bc}}$ & $4.3 \pm 0.20^{\text {cd }}$ & $4.2 \pm 0.10^{\mathrm{abc}}$ & $4.1 \pm 0.20^{\text {cd }}$ \\
\hline & 28 & $3.8 \pm 0.18^{\mathrm{a}}$ & $3.6 \pm 0.10^{\mathrm{a}}$ & $4.1 \pm 0.11^{\mathrm{ab}}$ & $3.9 \pm 0.30^{\mathrm{a}}$ & $3.9 \pm 0.20^{\mathrm{ab}}$ \\
\hline
\end{tabular}

Values are given as mean $\pm \mathrm{SD}$.

Different letters in the same column indicate significant differences $(\mathrm{P}<0.05)$.

noted that the viability of both probiotic bacteria were significantly greater in the treatments containing artichoke extract compared to control yoghurts during storage period of 28 days. Similarly, Mocanu et al. (2010) observed that highest number of probiotic bacteria at the end of refrigerate storage, belongs to yoghurt containing mixture of bilberry and liquorice extract compared to control yoghurt.

The antioxidant compounds in grapes can affect the survival of probiotics in yoghurt. But in some studies, the authors did not find an inhibitory effect (Hervert-Herna'ndez et al. 2009, Chouchouli et al. 2013). It is possible that phenolic compounds are transformed into more active derivatives (e.g. aglycones) under certain conditions, which might enhance starter culture activity (Sun-Waterhouse et al. 2013). In our study, after 28 days of storage, in all cases (even control treatment) the viable numbers of probiotics remained in values higher than $10^{6} \mathrm{cfu} / \mathrm{mL}$ that is necessary to confer the probiotic character of the products.

\section{Effect of incorporation of grape pomace powder on sensory properties of probiotic yoghurt}

Fruit mixes improve the nutritional value and the taste of yoghurt, and fruit enhancement plays a considerable role in yoghurt consumption and sales (Kailasapathy et al. 2008). Sensory properties of yoghurt samples prepared in this study are shown in Table 3. Sensory scores decreased during storage period. This could be attributed to the development of acidity. Similar results reported by Cakmakci et al. (2012) about probiotic banana 
yoghurts. Regarding appearance attribute there was not significant differences between samples (Table 3).

The lowest appearance (3.8) and taste (3.6) scores were obtained for sample containing 4\% GPP at 28 day storage, and the lowest consistency (4.0), flavor (3.8) and overall acceptability (3.8) scores were obtained for control sample at the end of storage period. While the highest sensory scores belonged to yoghurt supplemented with 2\% GPP at 0 day $(5.0,4.8,4.9,5.0$ and 4.9 respectively). In our study, the addition of grape pomace has no negative effect on the color of yoghurt samples. In parallel with our results, Dos Santos et al. (2017) observed the higher sensory scores for flavor, color, and overall acceptability about fermented goat milk added with grape pomace extract. In the study done by Chouchouli et al. (2013) the fortification of full-fat and non-fat yoghurts with grape seed extracts did not cause major defects in consistency, color and flavor compared to controls. Also in a research carried out by Da Silva et al. (2017), sensory attributes (color, flavor, taste, texture and appearance) of probiotic yoghurt supplemented with grape extract were acceptable by panelists. These findings proved that fruity yoghurt contains both the refreshing flavor and taste of fruit and beneficial effect of yoghurt (Mahmood et al. 2008). In current study, storage period had slightly effect on all attributes. According to this result grape pomace yoghurt at $2 \%$ has the most acceptability in point view of consumer (Table 3). Since grape pomace can be used in the production of probiotic yoghurt.

\section{Conclusions}

Grape pomace is a nutritious, but underused, by-product of winemaking containing fiber and antioxidants. Using a suitable production design, a new probiotic fortified yoghurt formulation with grape by-product could be optimized to enhance consumers' daily intake of antioxidants. The use of grape pomace powder in the development of value added food products will be a step toward making new functional foods, and partially solving waste management problem from wine production. As consumption of fruits, prebiotics and yoghurt in combination has a potential to provide extra nutritional-physiological value that involve in synergetic effect on health. The results of this study would provide an opportunity of dairy producer to develop a novel product in agreement with consumers' preferences. This research represents a new approach in the development of novel probiotic yoghurt with high nutritional quality for human and with great potential applications on food industry.

\section{References}

Abd El-Salam MH, El-Shibiniy S, Mahfuz MB, El-Dein HF, El-Atriby H, Antila V (1991) Preparation of whey protein concentrate from salted whey and its use in yoghurt. Dairy Res 58: 503-510

Agte V, Khetmalis N, Nilegaonkar S, Karkamkar S, Yadav S (2010) Prebiotic potential of 'juice grape' varieties and some hybrids. scientific and industri Res $69: 850-854$
Ahmadi E, Mortazavian AM, Fazeli MR, Ezzatpanah H, Mohammadi R (2012) The effects of inoculants variables on the physicochemical and organoleptic properties of Doogh. Int J Dairy Technol 2: 274281

AOAC. Official methods of analysis. (1990). 16th ed. Assoc. Off. Anal. Chem., Arlington, VA. Apostolidis E, Kwon YI, Shetty K (2007) Inhibitory potential of herb, fruit, and fungal enriched cheese against key enzymes linked to type 2 diabetes and hypertension. Innovat Food Sci Emerg Technolo 8: 46-54

Ayadi MA, Abdelmaksoud W, Ennouri M, Attia H (2009) Cladodes from Opuntia ficus indica as a source of dietary fiber: Effect on dough characteristics and cake making. Industri Crop Product 30: 40-47

Cakmakci S, Cetin B, Turgut T, Gurses M, Erdogan A (2012) Probiotic properties, sensory qualities, and storage stability of probiotic banana yogurts. Turk J Vete Anim Sci 36: 231-237

Cheng VJ, Bekhit AEDA, Sedcole R, Hamid N (2010) The impact of grape skin bioactive functionality information on the acceptability of tea infusions made from wine by-products. Food Scie 75: 167-172

Chouchouli V, Kalogeropoulos N, Konteles SJ, Karvela E, Makris DP, Karathanos VT (2013) Fortification of yoghurts with grape (Vitis vinifera) seed extracts. LWT - Food Sci Technol 53: 522-529

Chung KT, Lu Z, Chou MW (1998) Mechanism of inhibition oftannic acid and related compounds on the growth of intestinal bacteria. Food Chem Toxicol 36: 1053-1060

Cruz AG, Cavalcanti RN, Guerreito LMR, Sant'Ana AS, Nogueira LC, Oliveira CAF, Bolini HMA (2013) Developing a prebiotic yogurt: rheological, physicochemical and microbiological aspects and adequacy of survival analysis methodology. Food Engine 114: $323-$ 330

Da Silva DF, Tenório Junior NN, Gomes RG, Dos Santos Pozza MS, Britten M, Matumoto-Pintro PT (2017) Physical, microbiological and rheological properties of probiotic yogurt supplemented with grape extract. Food Sci Technol 54: 1608-1615

Djeridane A, Yousfi M, Nadjemi B, Boutassouna D, Stocker P, Vidal N (2006) Antioxidant activity of some Algerian medicinal plants extracts containing phenolic compounds. Food Chem 97: 654-660

Dos Santos KMO, Oliveira IC, Lopes MAC, Cruz APG, Buriti FCA, Cabral LM (2017) Addition of grape pomace extract to probiotic fermented goat milk: the effect on phenolic content, probiotic viability and sensory acceptability. J Sci Food Agri 97: 1108-1115

Ehsani J, Mortazavian AM, Khomeiri M, Ghasem Nejad A (2015) Effects of artichoke (Synara scolymus L.) extract addition on microbiological and physio-chemical properties of probiotic yoghurt. 2015. J Microbiol, Biotechnol Food Sci 4: 536-541

Espírito-Santo AP, Silva RC, Soares FASM, Anjos D, Gioielli LA, Oliveira MN (2010) Açai pulp addition improves fatty acid profile and probiotic viability in yoghurt. Intern Dairy J 20: 415-422

Ferdousi R, Rouhi M, Mohammadi R, Mortazavian AM, Khosravi- Darani K, Homayouni Rad A (2013) Evaluation of probiotic survivability in Yogurt exposed to cold chain interruption. Iran J Pharmaceu Res 12: $139-144$

Gibson GR, Roberfroid MB (1995) Dietary modulation of the human colonic microbiota: introducing the concept of prebiotics. J Nutr 71: 1401-1412

Gil-Sánchez I, Ayuda-Durán B, González-Manzano S, Santos-Buelga C, Cueva C, Martín-Cabrejas MA, Bartolomé B (2017) Chemical characterization and in vitro colonic fermentation of grape pomace extracts. J Sci Food Agri 97: 3433-3444 http://dx.doi.org/10.1002/ jsfa.8197. in press.

Gomes AMP, Malcata FX (1999) Bifidobacterium spp. and Lactobacillus acidophilus: biological, biochemical, technological and therapeutical properties relevant for use as probiotics. Trend Food Sci Technol 10: $139-157$

Hervert-Herna'ndez D, Pintado C, Rotger R, GoñI I (2009) Stimulatory role of grape pomace polyphenols on Lactobacillus acidophilus growth. Int J Food Microbiol 136: 119-122 
Hull RR, Roberts AV, Mayes JJ (1984) Survival of Lactobacillus acidophilus in yogurt. Austra J Dairy Technol 39: 164-166

Jang IC, Jo EK, Bae MS, Lee HJ, Jeon GI, Park E, Yuk HG, Ahn GH, Lee SC (2010) Antioxidant and antigenotoxic activities of different parts of persimmon (Diospyros kaki cv. Fuyu) fruit. J Medicin Plan Res 4: $155-160$

Kailasapathy K, Harmstorf I, Phillips M (2008) Survival of Lactobacillus acidophilus and Bifido bacterium animalis ssp. lactis in stirred fruit yogurts. Food Sci Technol 41: 1317-1322

Karaaslan M, Ozden M, Vardin H, Turkoglu H (2011) Phenolic fortification of yogurt using grape and callus extracts. LWT - Food Sci Technol 44: $1065-1072$

Karaman S, Toker ÖS, Yüksel F, Çam M, Kayacier A, Dоðаn M (2014) Physicochemical, bioactive, and sensory properties of persimmon-based ice cream: technique for order preference by similarity to ideal solution to determine optimum concentration. J Dairy Sci 97: 97-110

Karnopp AR, Oliveira KG, De Andrade EF, Postingher BM, Granato D (2017) Optimization of an organic yogurt based on sensorial, nutritional, and functional perspectives. Food Chem 233: 401-411

Korbekandi H, Mortazavian AM, Iravani S (2011) Stability and technology of probiotic in fermented milks: In: probiotic and prebiotic foods: technology, stability and benefits to the human health, (Shah N, ed.) Nova Science Publishing Ltd, USA. pp. 131-169

Kourkoutas Y, Bosnea L, Taboukos S, Baras C, Lambrou D, Kanellaki M (2006) Probiotic cheese production using Lactobacillus casei cells immobilized on fruit pieces. J Dairy Sci 89: 1439-1451

Lachman J, Hejtmánkováa A, Hejtmánkováa K, Stepánka H, Pivec V, Skala O, Pribyl J (2013) Towards complex utilisation of winemaking residues: characterisation of grape seeds by total phenols, tocols and essential elements content as a by-product of winemaking. Indust Crop Produc 49: 445-453

Lee WJ, Lucey JA (2010) Formation and physical properties of yogurt. Asia-Austral J Anim Sci 23: 1127-1136

Leong LP, Shui G (2002) An investigation of antioxidant capacity of fruits in Singapore markets. Food Chem 76: 69-75

Llobera A, Cañellas J (2007) Dietary fibre content and antioxidant activity of Manto Negro red Grape (Vitis vinifera): pomace and stem. Food Chem 101: 659-666

Mahmood A, Abbas N, Gilani AH (2008) Quality of stirred buffalo milk yoghurt blended with apple and bananafruits. Pakis J Agri Sci 45: 2 275- 279

Marchiani R, Bertolino M, Belviso S, Giordano M, Ghirardello D, Torri L, Zeppa G (2016) Yogurt enrichment with grape pomace: effect of grape cultivar on physicochemical, microbiological and sensory properties. Food Qual 39: 77-89

Martins A, Barros L, Carvalho AM, Santos-Buelga C, Fernandes IP, Barreiro F, Ferreira ICFR (2014) Phenolic extracts of Rubus ulmifolius Schott flowers: characterization, microencapsulation and incorporation into yogurts as nutraceutical sources. Food Func 5: 1091-1100

Mocanu D, Rotaru G, Botez E, Andronoid D, Nistor O (2010) Probiotic yogurt with medicinal plants extract: Physical-chemical, microbiological and rheological characteristics. J Agroalimen Proces Technol 16:469-476

Mortazavian AM, Ehsani MR, Azizi A, Razavi SH, Mousavi SM, Sohrabvandi S (2008) Viability of calcium alginate-microencapsulated probiotic bacteria in Iranian yogurt drink (Doogh) during the refrigerated storage period and under the simulated gastrointestinal conditions. Austral J Dairy Technol 63: 24-29

Öztürk BA, Oner MD (1999) Production and evaluation of yogurt with concentrated grape juice. J Food Sci 64: 530-532

Pereira DI, Gibson GR (2002) Effects of consumption of probiotics and prebiotics on serum lipid levels in humans. Critic Rev Biochem Mole Biol 37: 259-281
Pharmaceutiques UDL (1995) Dietary modulation of the human colonie microbiota: Introducing the concept of prebiotics. J Nutri 125: 1401-1412

Ramos LR, Santos JS, Daguer H, Valese AC, Cruz AG, Granato D (2017) Analytical optimization of a phenolic-rich herbal extract and supplementation in fermented milk containing sweet potato pulp. Food Chem 221: 950-958

Rasic JL, Kurmann JA (1978) Yogurt: Scientific Grounds, Technology, Manufacture and Preparations. Staempli Cie AG, Berne, Switzerland

Schieber A, Stintzing FC, Carle R (2001) By-products of plant food processing as a source of functional compounds. Recent developments (Review). Tren Food Sci Technol 12: 401-413

Senadeera SS, Prasanna PHP, Jayawardana NWIA, Gunasekara DCS, Senadeera P, Chandrasekara A (2018) Antioxidant, physicochemical, microbiological, and sensory properties of probiotic yoghurt incorporated with various Annona species pulp. Heliyon 4, https:// doi.org/10.1016/j.heliyon.e00955.

Sendra E, Fayos P, Lario Y, Fernandez-Lopez J, Sayas-Barbera E, PerezAlvarez JA (2008) Incorporation of citrus fibers in fermented milk containing probiotic bacteria. Food Microbiol 25: 13-21

Shafiee G, Mortazavian AM, Mohammadifar MA, Koushki MR, Mohammadi AR, Mohammadi R (2010) Combined effects of drymatter content, incubation temperature and final $\mathrm{pH}$ of fermentation on biochemical and microbiological characteristics of probiotic fermented milk. Afric J of Microbiol Res 4: 1265-1274

Sohrabvandi S, Mortazavian AM, Dolatkhah-Nejad MR, Bahadori Monfared A (2012) Suitability of MRS-bile agar for the selective enumeration of mixed probiotic bacteria in presence of mesophilic lactic acid cultures and yogurt bacteria. Iran J Biotechnol 10: 16-21

Sousa EC, Uchoa-Thomaz AMA, Carioca JOB, De Morais SM, De Lima A, Martins CG, Alexandrino CD, Ferreira PAT, Rodrigues ALM, Rodrigues SP, Silva JDN, Rodrigues LL (2014) Chemical composition and bioactive compounds of Grape pomace (Vitis vinifera L.), Benitaka variety, grown in the semiarid region of Northeast Brazil. Food Sci Technol (Campinas) 34: 135-142

Sowbhagya HB, Suma FP, Mahadevamma S, Tharanathan RN (2007) Spent residue fromcumin - a potential source of dietary fiber. Food Chem 104: $1220-1225$

Sun-Waterhouse D, Teoh A, Massarotto C, Wibisono R, Wadhwa S (2010) Comparative analysis of fruit-based functional snack bars. Food Chem 4: 1369-1379

Tammime AY, Saarela M, Korslund Sondergaard A, Mistry VV, Shah NP (2005) In: Probiotic Dairy Products, (Tamime, AY, ed) Blackwell Publishing Ltd, UK

Tarakci Z (2010) Influence of Kiwi Marmalade on the Rheology Characteristics, Color Values and Sensorial Acceptability of Fruit Yogurt. Kafkas Universitesi Veteriner Fakultesi Dergisi 16: 173178

Tarakci Z, Kucukoner E (2003) Physical, chemical, microbiological and sensory characteristics of some fruit-flavored yoghurt, YYU Vet Fak Dergisi 14: 10-14

Trachoo N, Mistry VV (1998) Application of ultrafiltered sweet buttermilk and sweet buttermilk powder in the manufacture of nonfat and low fat yogurts. Dairy Sci 81: 3163-3171

Vinderola CG, Reinheimer JA (1999) Culture media for the enumeration of Bifidobacterium bifidum and Lactobacillus acidophilus in the presence of yogurt bacteria. Int Dairy J 9: 497-505

Zainoldin KH, Baba AS (2009) The effect of Hylocereus polyrhizus and Hylocereus undatus on physicochemical, proteolysis and antioxidant activity in yogurt. Eng Technol 60: 361-366

Zheng W, Wang SY (2001) Antioxidant activity and phenolic compounds in selected herbs. J Agri Food Chem 49: 5165-5170

Zhu FM, Du B, Li J (2014) Effect of ultrafine grinding on physicochemical and antioxidant properties of dietary fiber from wine Grape pomace. Food Sci Technol Int 1:55-62 